IZA DP No. 7251

Social Learning and Health Insurance Enrollment:

Evidence from China's New Cooperative Medical Scheme

Hong Liu

Qi Sun

Zhong Zhao

February 2013 


\title{
Social Learning and Health Insurance Enrollment: Evidence from China's New Cooperative Medical Scheme
}

\author{
Hong Liu \\ Central University of Finance and Economics \\ Qi Sun \\ Shanghai University of Finance and Economics \\ Zhong Zhao \\ Renmin University of China \\ and IZA
}

Discussion Paper No. 7251

February 2013

\author{
IZA \\ P.O. Box 7240 \\ 53072 Bonn \\ Germany \\ Phone: +49-228-3894-0 \\ Fax: +49-228-3894-180 \\ E-mail: iza@iza.org
}

\begin{abstract}
Any opinions expressed here are those of the author(s) and not those of IZA. Research published in this series may include views on policy, but the institute itself takes no institutional policy positions. The IZA research network is committed to the IZA Guiding Principles of Research Integrity.

The Institute for the Study of Labor (IZA) in Bonn is a local and virtual international research center and a place of communication between science, politics and business. IZA is an independent nonprofit organization supported by Deutsche Post Foundation. The center is associated with the University of Bonn and offers a stimulating research environment through its international network, workshops and conferences, data service, project support, research visits and doctoral program. IZA engages in (i) original and internationally competitive research in all fields of labor economics, (ii) development of policy concepts, and (iii) dissemination of research results and concepts to the interested public.
\end{abstract}

IZA Discussion Papers often represent preliminary work and are circulated to encourage discussion. Citation of such a paper should account for its provisional character. A revised version may be available directly from the author. 


\section{ABSTRACT \\ Social Learning and Health Insurance Enrollment: Evidence from China's New Cooperative Medical Scheme*}

This paper examines the role of social learning in household enrollment decisions for the New Cooperative Medical Scheme in rural China by estimating a static game with incomplete information. Using a rich dataset from the China Health and Nutrition Survey, we find that the social network effects in the enrollment decision are large and significant. Furthermore, we use temporal and spatial proximity among household heads and obtain the result that the primary mechanism for the social network effects is social learning. Our findings indicate that a 10-percentage-point increase in the enrollment rate in a village increases one's take-up probability by 5 percentage points. We also find that the importance of social learning decreases significantly with the development of alternative information channels. Finally, the evidence suggests that healthier, wealthier, relatively well-educated older male household heads with Han nationality tend to be opinion leaders.

JEL Classification: I1, G22

Keywords: rural China, health insurance, social learning, social effect

Corresponding author:

Qi Sun

Shanghai University of Finance and Economics

777 Guoding Road

Shanghai

China

E-mail: sun.qi@mail.shufe.edu.cn

\footnotetext{
* We would like to thank seminar participants at Renmin University of China, Peking University, the University of Canberra, and 4th CIER/IZA Annual Workshop on Research in Labor Economics for helpful comments. This research uses data from the China Health and Nutrition Survey (CHNS). We thank the National Institute of Nutrition and Food Safety, China Center for Disease Control and Prevention; the Carolina Population Center, University of North Carolina at Chapel Hill; the National Institutes of Health (NIH; R01-HD30880, DK056350, and R01-HD38700); and the Fogarty International Center, $\mathrm{NIH}$, for financial support for the CHNS data collection and analysis files since 1989. We thank those parties, the China-Japan Friendship Hospital, and the Ministry of Health for support for CHNS2009 and future surveys.
} 


\section{Introduction}

One of the main obstacles to social program take-up is a lack of information about the program (Currie, 2006; Craig, 1991). For instance, Aizer (2007) finds that information costs are an important contributor to the low take-up rate in the Medicaid program in the United States. This problem could be more serious in developing countries, as the official information transmission channels are typically inadequate. However, such informational barriers could be reduced if information were transmitted through social learning and peer interaction.

The main objective of this paper is to quantify the importance of social learning in household health insurance enrollment decisions, exploiting the unique opportunity of the recent establishment and expansion of the New Cooperative Medical Scheme (NCMS) in rural China since 2003. The NCMS is a voluntary public health insurance program to provide health care coverage for the rural population and is one of the pillars of China's social security system.

In the context of the NCMS, social learning may play a significant role in enrollment decisions and it is worth investigating for four reasons. First, as the NCMS is implemented in rural China, issues related to information barriers could be more serious because of the low education level of the rural population ${ }^{1}$, a poor official information sharing scheme and less transparent government policies.

Second, the operation of the insurance market in general is still new and complex for most households in rural China. Information on the procedures, payoffs and costs associated with the NCMS per se is limited because it is a newly established program. Although local government officials have exerted considerable efforts such as an intensive advertising campaign and door-to-door appeals (Wu et al., 2006; You and Kobayashi, 2009) to convey information to rural households, the details of the NCMS program are still difficult for rural households to understand. For example, Pan et al. (2009) find that approximately 78 percent of survey respondents were unfamiliar with

\footnotetext{
${ }^{1}$ The overall education level of the Chinese rural population is quite low, with an average of 6.4 years of schooling based on CHNS data.
} 
the detailed NCMS regulations implemented in their counties.

Third, some studies find that when the NCMS was introduced, people had low levels of trust in local governments and were skeptical about the promised benefits of the NCMS, as the local governments had consistently imposed a number of taxes and fees on them but misused those funds in the past (Yip and Hsiao, 2009; Yi et al., 2011). Rural residents' distrust of government, combined with their low education levels and the complexity of the NCMS program, may substantially reduce the effectiveness of the official information campaign, and increase information barriers.

Finally, during the implementation phase of the NCMS, the social norms regarding and perceptions of the program were still being formed. Households in rural China typically live in close-knit villages, where they can effectively communicate with others. An individual villager can learn additional useful information from the behavior of his co-villagers, who might have better knowledge of or experience with health insurance, through word-of-mouth communication or observational learning. Therefore, social interactions and information exchanges among peers could have a long-term equilibrium effect on the take-up rate of the NCMS, which may be above or below than the optimal level (Dahl et al., 2012).

Relative to a growing body of literature studying different aspects of public insurance programs in China, such as design and implementation (Mao, 2005; Brown et al., 2009), and impact evaluation (Yip et al., 2008; Wagstaff et al., 2009, Lei and Lin, 2009), our study contributes to the literature by investigating the determinants of NCMS participation, with a particular focus on the role of social learning at the village level. Specifically, we aim to examine whether an individual's decision to enroll in the NCMS is affected by the decisions of his co-villagers, using data from the three most recent waves, 2004, 2006 and 2009, of the China Heath and Nutrition Survey (CHNS).

Our paper also contributes to the growing body of empirical literature on the importance of social learning in numerous contexts (Manski, 2000), such as health insurance plan decisions (Sorenson, 2006), group lending (Li et al., 2012), retirement savings decisions (Duflo and Saez, 2002; 2003), welfare participation (Bertrand et al., 
2000; Dahl et al., 2012), and stock market participation (Hong et al., 2005). Our work is distinct from those listed above in the sense that during our 5-year data period, the NCMS passed through different stages, from inception to expansion and to full coverage, which allows us to investigate the peer effects during different stages of the program.

Our empirical strategy also differs from the current practice in the literature. It is well known that the effect of social interactions is difficult to identify due to the mixture of endogenous peer decisions, simultaneous causality among peers, unobserved common factors within the peer group and the endogenous selection of peer group members (Manski, 1993; 2000). The existing literature generally adopts one of three approaches to overcome the identification problems. One is to use instrumental variables (e.g., Duflo and Saez, 2002; Chen et al., 2010) to account for the endogeneity of peers' decision. The second approach is to focus on a certain subsample and impose certain assumptions regarding the pattern of social interactions to overcome the simultaneity problem. For example, Sorensen (2006) studies peer effects on the health plan choices of newly hired employees by assuming that their choices are influenced by the existing employees, but not vice versa. The third approach is to study the problem using a randomized experiment (e.g., Duflo and Saez, 2003; Cai et al., 2009).

In this paper, we adopt a different approach to identify the peer effect using observational data. We model the NCMS participation process as a static game with incomplete information, in which households make NCMS enrollment decisions based on their own household-level characteristics (some of which are not observed by other villagers), village-level characteristics, and the enrollment decisions of other households in the same village. There are several reasons that this model is applicable to a social learning context. First, other households' enrollment decisions may reveal useful information about an NCMS plan that a particular household does not have. Second, the benefits that a particular household can obtain from the NCMS crucially depend on the overall enrollment rate. Third, rural residents may also have a desire to conform to the behavior of other households in the village (Banerjee, 1992). 
Therefore, other households' enrollment decisions may have a significant influence on an individual household, and households may make enrollment decisions strategically. However, each household may possess some private information about their own benefits and costs associated with enrollment. Therefore, we assume that households in each village participate in an incomplete information game.

The structure and role of the village in rural Chinese life make the village a natural peer group (we will discuss this further in Section 2), which helps to avoid the issue of endogenous group membership. We follow Bajari et al. (2010) and apply a two-step approach to account for the endogeneity of observed peer enrollment decisions. In addition, due to the panel nature and the richness of the dataset, we can further distinguish the effect of social learning from common unobservable factors through different model specifications.

We find that a 10-percentage-point increase in the enrollment rate of other households in the same village increases one's own take-up probability by 5 percentage points. We use temporal and spatial proximity among household heads to further ascertain that the most likely mechanism for the peer effect described above in NCMS enrollment decisions is information transmission via social learning. We also find that the importance of social learning decreases significantly with the development of alternative information channels. Our results also suggest that healthier, wealthier, relatively well-educated, and older male household heads with Han nationality tend to be opinion leaders. Finally, low income families and families living in relatively poor villages are influenced by social effects to a greater extent.

The remainder of the paper is organized as follows. Section 2 briefly describes the institutional background of the NCMS in China. Section 3 outlines our econometric model and the estimation strategy. Section 4 describes the data and main variables. Section 5 presents our empirical findings, and Section 6 concludes.

\section{Background}

Prior to the economic reforms of the late 1970s, a village-based rural health 
insurance system, known as the Cooperative Medical Scheme (CMS), covered 90 percent of Chinese rural residents and was their primary channel for accessing basic health services (Feng et al., 1995; Liu, 2004b; You and Kobayashi, 2009). Along with the transition from the collective commune system to the "household responsibility system” beginning in 1978, the CMS collapsed in most rural areas because it lost its main financial support from the collective commune welfare fund. The health insurance coverage rate dropped dramatically from 90\% in 1980 to 5\% in 1985 (Liu and Cao, 1992). Since then, most rural residents have remained uninsured. According to the China National Health Service Survey, over 87 percent of the 0.9 billion rural residents did not have any health insurance in 1998 (Liu, 2004a), and the uninsured rate was still nearly 80 percent in 2003.

To improve health care access for rural residents, the Chinese government began to implement a nationwide project known as the New Cooperative Medical Scheme (NCMS) in rural China in 2003. It was first implemented in 304 pilot rural counties, was expanded to 1451 counties (approximately 50 percent of all rural counties) in 2006, and to nearly all rural counties (approximately 95 percent) by 2008. This program covered 835.6 million rural residents in 2010, or nearly two-thirds of the Chinese population.

According to the broad guidelines issued by the central government, the NCMS is a voluntary public insurance program operated at the county level. The NCMS seeks to provide low-cost basic health care services, including inpatient, catastrophic, and some types of outpatient care, for the entire rural population. To reduce the adverse selection associated with the voluntary nature of the NCMS, participation in the NCMS is determined at the household level. ${ }^{2}$

The details of the NCMS plans are complicated and vary across counties. For example, the funding for the NCMS comes from three main sources, including subsidies from the central government, from local (mainly provincial) governments, and individual contributions. The shares of contributions from different sources differ

\footnotetext{
${ }^{2}$ Despite this requirement, some local governments also allow for enrollment at the individual level in practice, to achieve high levels of enrollment.
} 
and change over time. The NCMS plans in all counties cover inpatient care, but differ in their coverage for outpatient services. Most counties cover outpatient services through a household account (approximately 65\%) or on a pooled basis (approximately 7\%). The rest cover only outpatient services for catastrophic diseases (approximately 11\%), or do not cover outpatient services at all (approximately 17\%) (Lei and Lin, 2009; You and Kobayashi, 2009; Wagstaff et al., 2009). The enrollees can only visit certain approved facilities to be eligible for reimbursement, and can be reimbursed immediately or later on at a health facility or other agency, depending on local policies. The reimbursement rates, deductibles and ceilings also vary across facility types. These complicated regulations inevitably generate considerable information costs and barriers for rural households.

Figure 1 shows the NCMS participation rate in rural China from 2004 to 2010, based on official national statistics. Surprisingly, the take-up rate of the NCMS was approximately 75 percent during the initial stage in 2004, increased steadily to 81 percent in 2006, and reached $96 \%$ in 2010 . Compared to many voluntary social programs in other countries, such as the Medicaid program in the United States, the high take-up rate of the NCMS is an achievement in itself. ${ }^{3}$

\section{[Insert Figure 1]}

Such high levels of participation may be the result of the relatively generous government subsidies for the NCMS and the household-based enrollment requirement (Wagstaff et al., 2007). However, as shown in Table 1, the village-level enrollment rates varied considerably, ranging from zero enrollment to full enrollment, ${ }^{4}$ within the NCMS counties when the NCMS was newly introduced in each wave. The estimated standard deviation within counties is approximately 0.19 , similar to the estimated standard deviation across counties, which cannot be explained by common NCMS policies at the county level. Therefore, it is important to understand the

\footnotetext{
${ }^{3}$ According to the studies summarized in Sommers et al. (2012), the estimated adult take-up rates in Medicaid range from $32.3 \%$ to $81.3 \%$.

${ }^{4}$ In our sample, each wave has a village with zero enrollment and a village with full enrollment.
} 
mechanism underlying the NCMS take-up decision and investigate what explains the high overall take-up rate and different take-up rates at the village level, which may have important implications for other social programs in China and in other countries in general.

\section{[Insert Table 1]}

Given the experiences of other developing and developed countries, a lack of information is an important barrier to participation in social programs (Moffitt, 1983; Currie, 2006), as learning about a program, its eligibility requirements and how to apply is costly and time-consuming (Kleven and Kopczuk, 2011). In this paper, we consider the possibility that NCMS participation is influenced by peer-group effects, which have been shown to be an important information transmission channel for individual decisions on program participation (Sorenson, 2006; Duflo and Saez, 2002; Bertrand et al., 2000; Dahl et al., 2012; Li et al., 2012).

Following the empirical literature on social learning in the context of rural societies (Foster and Rosenzweig, 1995; Munshi, 2004), we define rural villages as peer groups, as each village in China is a closely-knit, long established social group (Chen et al., 2010; Brown et al., 2011). A typical village in China consists of 50 to 100 families and approximately 500 individuals, who belong to perhaps 7 to 10 clans. Most villagers live within walking distance of one another, and usually know each other well, due to the low population mobility resulting from the restrictions imposed by the household registration system (Hukou) and close local ties spanning generations. Mangyo and Park (2011) also show that geographic reference groups are more salient for rural residents than urban residents in China. Therefore, presumably, rural residents in the same village may learn much of the information on application procedures, reimbursement hassles, choice and the quality of the facilities from each other through formal or casual/word-of-mouth communications or by observational learning. 


\section{Econometric Specification}

To estimate the strength of this social learning effect, we follow Sorenson (2006), and assume that exogenous peer effects (Manski, 1993; 2000) are not applicable in health insurance settings, as it is unlikely that the characteristics of co-villagers directly affect individuals’ insurance take-up behavior. Nevertheless, as Manski (1993) states, there are three endogeneity issues that may bias the estimation: simultaneous causality, common unobservables, and endogenous selection into peer groups. In our empirical analysis, the issue of selection into peer groups is not a concern, as villages are naturally occurring peer groups as described in section 2, and migration into or out of a village is restricted by the Hukou system. Due to the restrictions of the Hukou system, it is impossible for rural residents to move to other villages to obtain NCMS benefits. We need to address the problem of common unobservables and separate the effect of social learning from the impact of common unobservables. For example, as another channel of information transmission, an unobserved local official information campaign may cause rural households in a village to make similar enrollment decisions. The positive correlation between an individual's decision and co-villagers' decisions could simply reflect unobserved, county-specific common NCMS policies, shared characteristics of health resources, correlated preferences, etc., instead of informational spillovers. Therefore, we model the NCMS participation process as a static game with incomplete information and control for unobserved common factors in several ways. In this section, we specify the econometric model, discuss identification conditions and present the estimation methods.

\subsection{Model}

In rural China, households from the same village are eligible for the same NCMS plan and the enrollment is at the household level in the sense that each household can choose to have either all or none of its household members participate. We index a village by $g$ where a particular NCMS plan is implemented, and a household that is 
eligible for NCMS by $i$. Let $y_{i g t}$ be the NCMS participation decision of household $i$, where $y_{i g t}=1$ indicates that household $i$ in village $g$ has chosen to participate in the NCMS in period $t$ and $y_{i g t}=0$ otherwise. The enrollment decision of household $i$, $y_{i g t}$, is determined by the following equation:

$$
y_{i g t}=x_{i g t} \beta+\delta\left(\frac{1}{N_{g}-1}\right) \sum_{j \neq i} y_{j g t}+z_{g t} \eta+c_{i}+\varepsilon_{i g t}
$$

The enrollment decisions of other households in the same village are summarized in the term $\left(\frac{1}{N_{g}-1}\right) \sum_{j \neq i} y_{j g t}$, which is the proportion of households other than $i$ from the same village that choose to participate in the NCMS in period $t$. The coefficient $\delta$ measures the direction and the magnitude of the village-level peer effect. The vector $x_{i g t}$ contains observed household characteristics, while $c_{i}$ represents an unobserved household or village characteristic that is fixed across $g$ and t. The vector $z_{g t}$ contains observed village-level characteristics, which provide contextual effect at village level. Finally, $\varepsilon_{i g t}$ is a stochastic preference shock that is i.i.d. across $i$ and $t$.

\subsection{Identification and Estimation}

We follow Bajari et al. (2010) and use a two-step procedure to estimate equation (1). The key idea is that, without unobserved heterogeneity, the enrollment probabilities $y_{i g t}$ are determined by $x_{i g t}$ and $z_{g t}$ alone. Therefore, a consistent estimator of the enrollment probabilities $y_{i g t}$ can be obtained based on $x_{i g t}$ and $z_{g t}$ through a flexible (e.g., nonparametric or semiparametric) estimation method in the first step, and these estimates can then be plugged into the right hand side of equation (1) to calculate the value of the variable $\left(\frac{1}{N-1}\right) \sum_{j \neq i} y_{j g t}$. In the second step, we can estimate equation (1) using the estimated value of $\left(\frac{1}{N-1}\right) \sum_{j \neq i} y_{j g t}$ from the first stage using the standard panel data estimation method.

A key identification issue is that both the term $\left(\frac{1}{N-1}\right) \sum_{j \neq i} y_{j g t}$ and the term 
$x_{i g t} \beta$ depend on the observed household characteristics $x_{i g t}$. This will cause a collinearity problem in the second step when we separately estimate $\beta$ and $\delta$. Therefore, the above two-step procedure requires the appropriate exclusion conditions to achieve identification (Bajari et al., 2010). In general, we need covariates that directly influence the decision of a particular household but do not directly influence other households. In this study, these covariates include variables that indicate the health status of the household, i.e., an indicator of whether the household head has chronic diseases and the number of household members with chronic diseases. This assumption implies that the NCMS enrollment decision of household $i$ is only directly determined by the health status of its own members but is not directly affected by the health status of other households $-i$ in the same village. The health status of other households $-i$ only affect household $i$ 's decision indirectly through peer effects. Therefore, if the health status of other households $-i$ are excluded from the term $x_{i g t} \beta$, in both stages of estimation, this collinearity problem can be solved.

Specifically, in the first step we regress the NCMS enrollment $y_{\text {igt }}$ on the two variables measuring household-specific health status characteristics, a household-level fixed effect, and a full set of time-village interactions. In addition, we employ a 3rd-order spline to allow for a flexible functional form in the first stage regression. Then, we calculate the fitted value $\hat{y}_{i g t}$, from the first stage regression and plug it into the right hand side of equation (1) to replace $y_{i g t}$.

In the second stage estimation, we control for the unobserved heterogeneity in several ways. First, in addition to household-level characteristics, we also control for a rich set of village-specific factors that influence the enrollment decisions of households in the village. Second, we control for time-invariant unobserved heterogeneity at the county (program), village and household levels using fixed effects specifications. Finally, we include a full set of province and wave dummies to control for regional differences and common time trends that could not be attributed to any of the explanatory variables in the model.

This two-step method has been widely used in estimating dynamic discrete 
industrial organization games (e.g., Aguirrehabiria and Mira, 2007; Bajari et al., 2007; Berry et al., 2007), and our model is a special case of such dynamic games with a zero discount rate.

\section{Data and Variables}

\subsection{Data}

Our data come from the China Health and Nutrition Survey (CHNS), conducted by the Carolina Population Center at the University of North Carolina Chapel Hill and the National Institute of Nutrition and Food Safety of the Chinese Center for Disease Control and Prevention. The CHNS is an ongoing longitudinal survey with eight waves of data in 1989, 1991, 1993, 1997, 2000, 2004, 2006, and 2009. It contains rich information on individual, household and community (or village in rural areas) characteristics, allowing researchers to study social and economic changes in China and their effects on the economic, demographic, health and nutritional status of the population.

The CHNS data cover nine of China’s 31 provinces, including Guangxi, Guizhou, Heilongjiang, Henan, Hubei, Hunan, Jiangsu, Liaoning, and Shandong, which differ considerably in geography, economic development, public resources, and public health conditions. These sample provinces host approximately 45 percent of China's total population. The CHNS uses a multistage, random cluster-sampling approach to construct the sample. In each sample province, counties were initially stratified into low, middle, and high income groups, and four counties were then randomly selected based on a weighted sampling scheme. The provincial capital and a low-income city are selected when feasible. Villages and townships were selected randomly within the counties, and urban and suburban neighborhoods within the cities. In 2004-2009, there were approximately 218 primary sampling units, consisting of 36 urban neighborhoods, 37 suburban neighborhoods, 37 town neighborhoods ${ }^{5}$ and 108 rural

\footnotetext{
${ }^{5}$ CHNS 2004 has only 35 town neighborhoods.
} 
villages, which are all entities legally identified by the National Bureau of Statistics of China, referred to as "communities" in the CHNS. In this paper, as we only use the rural sample, we use “communities” and "villages” interchangeably.

In this study, we use the last three waves of CHNS data (2004, 2006, 2009) and focus on rural residents in rural areas, ${ }^{6}$ including approximately 3000 households each wave. For the purposes of this study, our sample is further restricted to households living in counties where the NCMS has been introduced. Although the CHNS has no survey questions directly related to NCMS status at the county level, the confidential community surveys collected information from the community head or community health workers and asked whether there was a Cooperative Medical Scheme in this community and if so for how long. As the NCMS was implemented in rural areas beginning in 2003, those villages where it was implemented in 2003 or later are considered NCMS villages. According to the government guideline that the NCMS should be managed at the county level, we classify a county with any village implementing the NCMS program as a NCMS county. Furthermore, based on the same survey questions, we can also determine when the NCMS was introduced in the county, that is, before 2004, between the 2004 and 2006 waves, or between the 2006 and 2009 waves.

In addition, we exclude approximately 9 percent of sample observations with missing values for health facility information at the community level and approximately 1 percent of sample households missing data on important demographic or socio-economic characteristics. The final study sample consists of 3,266 households, including 233 in 2004, 866 in 2006, and 2,167 in 2009. Table 2 presents the main variables and summary statistics.

\section{[Insert Table 2]}

\footnotetext{
${ }^{6}$ According to the administrative definition in China, city neighborhoods and county towns are regarded as urban areas, while suburban and rural villages are treated as rural areas.
} 


\subsection{Variables}

The dependent variable is a dichotomous measure indicating household participation in NCMS. In the 2004 and 2006 waves, the CHNS asked each respondent whether he/she had cooperative medical insurance, but made no distinction between old and new schemes. In the 2009 wave, respondents were asked specifically about enrollment status in the NCMS. As the study sample is restricted to counties where the NCMS has been implemented, it is reasonable to consider the CMS enrollees in the NCMS counties as NCMS participants in the 2004 and 2006 waves. We use the household head's participation status as the primary measure of household enrollment. It is coded 1 if the household head is enrolled in NCMS and 0 otherwise. Using this measure, we find that $58 \%$ of the households in 2004 , $74 \%$ in 2006, and 93\% in 2009 selected to participate in the NCMS. ${ }^{7}$

In the empirical model, we also control for the demographic and economic characteristics of the household and village characteristics. Individual- and household-level variables include age, gender, nationality, marital status, the presence of chronic disease (hypertension, diabetes, heart disease, stroke, and asthma), and education level (illiterate, primary school, junior high school and above) of the household head, household size, total household income (in 2009 Chinese RMB ), the number of children under age 18, the number of elderly family members over 60 , and the number of family members with chronic diseases. Village-level variables include village population density, presence of a health facility, physician density, presence of health insurance in 2000, prevalence of major chronic diseases, and the community urbanicity index developed by Jones-Smith and Popkin (2010), which reflects the levels of development and urbanization.

\footnotetext{
${ }^{7}$ These coverage rates based on our sample are slightly lower than national statistics. It is probably because our sample size is much smaller, especially in wave 2004. And our calculations are at household level, whilst national statistics are based on individual data.
} 


\section{Results}

\subsection{Baseline Effect of Social Learning on NCMS Enrollment}

Table 3 presents our baseline results using the two-step approach. We omit the results from first stage and only report the second-stage results. We have two specifications for the second stage estimation: random effects (RE) and fixed effects (FE) models. For comparison, we also conduct RE and FE estimations without peer effects and using the simple average enrollment in the village to replace the estimates from the first-stage as the key independent variable.

[Insert Table 3]

As shown in columns (3) and (4), we find that the co-villagers' enrollment decisions have had a significant effect on an individual household's take-up probability. However, the coefficients $(0.73-0.74)$ based on the reduced form regressions tend to overestimate the actual magnitude of social effects because they fail to address the endogeneity problem caused by simultaneous causality and correlated unobservables (Manski, 1993). After eliminating the endogeneity bias using the two-step approach in columns (5) and (6), we still find a significant positive social effect, but the estimates are much smaller, approximately two-thirds the size of the reduced form estimates. Both the RE and FE estimates show statistical significance at the 1 percent level. The FE estimate is smaller than the RE estimate, but the magnitude, 0.50, is still economically large, suggesting that a 10-percentage-point increase in the enrollment rate of other households in the same village increases a household's take-up probability by 5 percent.

To place the importance of this social effect in the proper perspective, we can compare our main estimate in column (6) to the impact of price on health insurance demand. Unfortunately, we cannot obtain price elasticity estimates for the NCMS because of the lack of data on premiums, and few studies estimate the price elasticity of health insurance demand in China. The literature indicates that the price elasticity 
of demand for non-group health insurance in the US ranges from -0.3 to -0.87 (Gruber and Poterba, 1994; Marquis and Long, 1995; Congressional Budget Office, 2005; Krueger and Kuziemko, 2011). Therefore, 10-percentage-point increase in the proportion of peer enrollment in this study has the same influence on individual enrollment probability as 6-16 percent decrease in insurance premiums in the US individual health insurance market.

Another way to understand the magnitudes of estimated social effects is to compare them to peer effects in other contexts. The study most similar to ours is Sorensen (2006), which examines individuals' choices of employer-sponsored health plans in California. He finds that the estimates for social effects are approximately 1.4-2.1, three to four times ours. However, in contrast to our study, Sorensen (2006) estimates discrete choice models, and his estimates suggest that 10-percentage-point increase in the share of a particular health plan in the department increases the probability that an employee will select this plan by 14-21 percent. In another study of the Chinese context, Chen et al. (2010) find that if the migration rate of the co-villagers increases by 10 percentage points, this will increase an individual's migration probability by 7.27 percent in rural China, which is slightly larger than our estimate.

\subsection{Non-Linearity of Social Effect on NCMS Enrollment}

In Table 4, we test for the presence of non-monotonic pattern of social effects in NCMS enrollment in two alternative ways. First, we add a quadratic term for peer enrollment in columns (1) and (2) and find that it is highly significant and negative, implying a concave pattern of social effects. The estimated turning point is 0.88 , above the $60^{\text {th }}$ percentile of the estimated peer enrollment, but very close to the extreme value.

[Insert Table 4]

To avoid erroneously accepting the hypothesis of an inverse U-shaped 
relationship, we also conduct linear spline regressions with two discontinuity points, 0.6 and 0.9 , corresponding to the $20^{\text {th }}$ and $70^{\text {th }}$ percentiles of peer enrollment. Consistent with the results from the quadratic specification, the results in columns (3) and (4) show that the social effect is approximately 1.5 in villages with peer enrollment rates below 60 percent, decreases to 0.7 when the peer enrollment rate is between 60 and 90 percent, and becomes statistically indistinguishable from 0 when the peer enrollment rate exceeds 90 percent. The concavity may suggest that at an early stage, information is more valuable and the villagers are more susceptible to peer influence. At a later stage, as the information diffuses, it becomes less useful because the peer-affected villagers were already in the program.

\subsection{Social Effect Mechanism}

In the subsection, we investigate whether the mechanism underlying the peer effects on NCMS enrollment is social learning or is driven by common unobservables. Social learning refers to any mechanism through which rural residents obtain helpful insurance information from their co-villagers to make enrollment decisions (Banerjee, 1992; Cai et al., 2009).

The theory of social interactions predicts that social learning is more important in the demand for complex or unfamiliar products. In other words, if the peer effect captures information sharing, it should have a greater impact on individual enrollment decision in villages that receive relatively less health insurance information. We test this proposition with three specifications. According to the implementation timing of the NCMS, we classify the sample counties into three groups: the NCMS programs introduced in the 2004, 2006 and 2009 waves. In the first specification, we estimate the social effects for only those counties where the NCMS newly established in each wave. As shown in columns (1) to (3) of Table 5, all of the social effects are significant in each wave. Peer enrollment has the highest impact in the NCMS pilot counties in the 2004 wave, when the NCMS was new to all rural residents. However, this peer effect is less than half as influential in newly added NCMS counties in the 
2009 wave, when individuals had already learned more about the NCMS from pilot counties before it was implemented in their own counties.

In the second specification, we examine the different sizes of the social effects in counties that had the NCMS for different lengths of time. Using CHNS 2009, we include interaction terms between peer enrollment and NCMS duration. The results in column (4) of Table 5 show that social effects are larger in villages where the NCMS was implemented more recently, while social effects decrease significantly in the amount of time since the NCMS was implemented. These findings provide evidence that social learning plays a more important role when people are unfamiliar with the NCMS.

\section{[Insert Table 5]}

Modern information and communication technologies may provide alternative channels for information dissemination besides peer interaction and reduce the strength of social learning within the village (Bikhchandani et al., 1998; Chen et al., 2010). In the third specification, we include interactions between peer enrollment and the development of information technology in each village, measured by overall communication scores constructed by Jones-Smith and Popkin (2012) ${ }^{8}$, and two binary variables indicating access to convenient internet and cell phone service in the village. As shown in Table 6, the interaction terms are negative and statistically significant. These estimates suggest that individuals are influenced less by co-villagers when they have more convenient access to modern communication systems, i.e., alternative informational channels, which is fully consistent with the social-learning hypothesis.

\section{[Insert Table 6]}

\footnotetext{
${ }^{8}$ The communication score is one of the 12 components of the urbanicity scale developed by Jones-Smith and Popkin (2012), based on CHNS data. They use 7 variables to operationalize the characteristics of the communication system in each community, including the availability (within community boundaries) of a cinema, newspaper, postal service, and telephone service and percent of households with a computer, the percent of households with a television, and the percent of households with a cell phone.
} 
The theory of social interactions also implies that the strength of the social effect should be greater for household pairs with spatial proximity (Munshi and Myaux, 2006; Bertrand et al., 2000), so that information can be transmitted through formal or casual/word-of-mouth communications. Each village in China is a closely-knit, long-established social network, and individuals usually tend to have more social interactions with others within the village than across villages. In Table 7, we separately estimate the social effects from peers in the same village, in other villages of the same county, and in other counties of the same province. The results show that the estimated social effects decline in spatial distance, implying that households are influenced more by their peers living in the same village than by others living in different villages or counties. This suggests that the estimated peer effects are most likely to capture the role of social learning, and not the effect of the common unobservables at the county level; otherwise, we should at least observe significant social effects from peers in other villages of the same county, as they share similar unobserved NCMS policy characteristics.

\section{[Insert Table 7]}

The similarity of households' enrollment decisions may also be driven by village-level common unobservables. Although we control for village-specific observable and time-invariant unobservable characteristics in the second-stage FE estimation, there is still a concern that time-varying, unobserved heterogeneity is responsible for our findings, e.g., a local official information campaign. In Table 8, we divide households into different subgroups within villages according to their observable demographic and socioeconomic characteristics and estimate the different social effects among subgroups. This analysis can help us separate the effect of social learning from the influence of village-level common unobservables (Duflo and Saez, 2002; Munshi and Myaux, 2006) and capture the pattern of social learning. Based on the conjecture that individuals may be more likely to interact with co-villagers who share common observable characteristics, we should observe stronger social effects 
within subgroups than across subgroups in the village (Sorensen, 2006; Duflo and Saez, 2002). If individuals' enrollment decisions are impacted by their observations of others' behavior, there may be opinion leaders in rural villages who appear to have expertise and the ability to make informed NCMS enrollment decisions (Bikhchandani et al., 1998). This analysis can determine the observable characteristics associated with occupying a leadership role.

\section{[Insert Table 8]}

Table 8 presents the estimated social effects from co-villagers within subgroups for households in the full sample and in each subgroup. We find significant symmetric and asymmetric social effects. The former is consistent with our prior conjecture, showing that the enrollment behavior of male (or Han) household heads is significantly affected by other male (or Han) household heads, but not by female (or minority) heads. Similar to Chen et al. (2010), we also find that younger heads (age 18-55) are significantly affected by those aged 55 and above, and female heads are significantly influenced by male heads; whereas the reverse effects are close to zero and within-group effects for these households are nearly absent. These findings imply that, on average, the behaviors of the older, male heads with Han nationality have the strongest effect on rural residents in the village.

Moreover, the results in panel 4 indicate that household heads with a low education level (below the $30^{\text {th }}$ percentile in the village) are significantly affected by the behavior of household heads with a medium education level (between the $30^{\text {th }}$ and $70^{\text {th }}$ percentiles in the village). Similarly, panel 5 of Table 8 shows that households with low (middle) income levels respond significantly to the enrollment rate of households with middle (high) incomes in the same village. We find no significant within-income-group or within-education-group effects. These findings are consistent with the theory of social learning. Households with low socioeconomic status may find the decisions of co-villagers with middle socioeconomic status more informative, 
due to their lack of relevant knowledge and their limited access to information resources. However, they are not significantly affected by those with high socioeconomic status in the village, partly because they lack common backgrounds and have fewer social interactions.

Overall, the results in Table 8 imply that wealthier, relatively well-educated, older, male household heads with Han nationality tend to be opinion leaders in NCMS enrollment in rural villages. Moreover, we do not find the presence of both within-subgroup effects and cross-subgroup effects in any regression specification in Table 8. This clear pattern provides supporting evidence that the social effect mechanisms is social learning rather than common unobservables at the village level.

\subsection{Policy Implications of Social Effect on NCMS Enrollment}

Social effects have important policy implications for the long run success of the NCMS. First, they can alleviate issue of adverse selection in NCMS participation. To illustrate this empirically, in column (1) of Table 9 we first add interactions between the social effects and indicators of the health status of household head and household members. The results indicate that social effects are stronger for households without chronic diseases than for those with chronic diseases. Moreover, when we estimate social effects for subgroups with or without chronic disease, we also find that both healthy and unhealthy households are significantly influenced by the average enrollment of their healthy co-villagers. This finding suggests that enrolling healthier households is important for the sustainability of the NCMS, not only because of its direct effect on risk pooling, but also because of its indirect effect through social influence.

\section{[Insert Table 9]}

Designed to reduce the poverty associated with poor health, the NCMS is more meaningful for poor households. With less relevant knowledge and limited information access, poor households are more likely to face information barriers in 
their enrollment decisions. The study of social effects helps us to better understand how individuals with different backgrounds obtain information through social learning, especially for the poor. In Table 8, we have already shown that poor households are significantly influenced by the behaviors of more affluent co-villagers. Furthermore, in Table 10 we include interactions between the peer effects and indicators for income groups and indicators for the community urbanicity index in the regressions. The urbanicity index reflects development on a wide range of village aspects, including infrastructure, education, and medical services. Households living in villages with higher urbanicity index scores may enjoy better resources in terms of education, information, and other aspects of acquiring necessary information about the NCMS. As expected, the results show that social effect is more influential for households with low household income and those living in relatively less developed villages. The significant negative coefficients on the low household income and low community urbanicity indicators suggest that without the role of social effects, households that are poor or from poor villages may have low NCMS participation rates.

[Insert Table 10]

\section{Conclusions}

In this paper, we investigate the importance of social learning in household NCMS enrollment decisions in rural China by modeling households' enrollment decisions as a static incomplete information game. In our model, households make their enrollment decisions based on their characteristics, village characteristics, and other households' enrollment decisions. We find that the NCMS enrollment probability of an individual household would increase by 5 percentage points if the enrollment rate of other households in the same village were to increase by 10 percentage points. From a policy perspective, such peer effects are equivalent to a social multiplier effect of 1.9 at the village level, based on the computation method 
proposed by Glaeser (2003).

We discuss and clarify how the identification problems can be resolved or overcome in this analysis to establish a causal relationship between social effects and household enrollment behavior.

First, we employ the two-step approach proposed by Bajari et al. (2010), together with household-level fixed effects, to control for the endogeneity of the village-level peer enrollment rate. This estimation strategy draws on the growing literature on estimating static discrete-choice games in industrial organization in which one agent's payoff is affected by other agents' decisions.

Second, using the rich information in our dataset, we conduct several specification tests to show that the mechanism for social effects in NCMS enrollment is primarily social learning. Specifically, we show that the role of social effects was more salient when individuals were unfamiliar with NCMS, and their influence increased with close geographical proximity, which is fully consistent with the theory of social learning (Sorensen, 2006; Munshi and Myaux, 2006). Moreover, we also find that the importance of social learning from co-villagers decreases significantly with the development of alternative information channels.

Third, we add to the literature by providing empirical evidence for asymmetric peer effects in the setting of health insurance enrollment. We find that healthier, older, Han, male household heads with higher education and income levels tend to be opinion leaders, especially for households with low socioeconomic status. This is consistent with the empirical finding of Nair et al. (2010) that research-active physicians significantly influence the behavior of other physicians but not vice versa. Thus, our results suggest that targeting opinion leaders in rural villages with an information campaign may have economically significant social multiplier effects on social programs.

Fourth, our evidence also suggests that low income families and families living in relatively poor villages were more influenced by social learning, which may have important implications for the evaluation of social programs.

Finally, our data allow us to investigate peer effects at different stages of a 
program: from inception, to expansion, and to full coverage. We find that the importance of the peer effects varies with the evolution of the program.

\section{References}

Aguirregabiria, V., Mira, P., 2007. Sequential estimation of dynamic discrete games. Econometrica 75(1), 1-53.

Aizer, A., 2007. Public health insurance, program take-up, and child health. Review of Economics and Statistics 89(3), 400-415.

Bajari, P., Benkard, L., Levin, J. 2007. Estimating dynamic models of imperfect competition. Econometrica 75(5), 1331-1370.

Bajari, P., Hong, H., Krainer, J., Nekipelov, D. 2010. Estimating static models of strategic interactions. Journal of Business and Economic Statistics 28(4), 469-482.

Banerjee, A. 1992. A simple model of herd behavior. Quarterly Journal of Economics 107(3), 797-817.

Berry, S., Pakes, A., Ostrovsky, M. 2007. Simple estimators for the parameters of dynamic games, with entry/exit examples. RAND Journal of Economics 38(2), 373-399.

Bertrand, M., Luttmer E., Mullainathan, S. 2000. Network effects and welfare cultures. Quarterly Journal of Economics 115(3), 1019-1055.

Bikhchandani, S., Hirshleifer, D., Welch, I. 1998. Learning from the behavior of others: conformity, fads, and informational cascades. The Journal of Economic Perspectives 12(3), 151-170.

Brown, P., Bulte, E., Zhang, X. 2011. Positional spending and status seeking in rural China. Journal of Development Economics 96(1), 139-149.

Brown, P., de Brauw, A., Du, Y. 2009. Understanding variation in the design of China's New Cooperative Medical System. The China Quarterly 198, 304-329.

Cai, H., Chen, Y., Fang, H. 2009. Observational learning: evidence from a randomized natural field experiment. American Economic Review 99(3), 864-882 
Chen, Y., Jin, G., Yue, Y. 2010. Peer migration in China. NBER Working Paper No. 15671.

Congressional Budget Office, 2005. The price sensitivity of demand for nongroup health insurance. Available at:

http://www.cbo.gov/ftpdocs/66xx/doc6620/08-24-HealthInsurance.pdf.

Craig, P. 1991. Costs and benefits: a review of research on take-up of Income-Related benefits. Journal of Social Policy 20(4), 537-565.

Currie, J. 2006. The take-up of social benefits. In: Auerbach, A., Card D., Quigley, J. (Eds). Public Policy and the Income Distribution. New York: USA, 80-149.

Dahl, G., Loken, K., Mogstad, M., 2012. Peer effects in program participation. NBER Working Paper No. 18198.

Duflo, E., Saez, E. 2002. Participation and investment decisions in a retirement plan: the influence of colleagues' choices. Journal of Public Economics 85(1), 121-148.

Duflo, E., Saez, E. 2003. The role of information and social interactions in retirement plan decisions: evidence from a randomized experiment. Quarterly Journal of Economics 118(3), 815-842.

Feng, X., Tang, S., Bloom, G., Segall, M., Gu, X. 1995. Cooperative medical schemes in contemporary rural China. Social Science and Medicine 41(8), 1111-1118.

Foster, A., Rosenzweig, M. 1995. Learning by doing and learning from others: human capital and technical change in agriculture. Journal of Political Economy 103(6), 1176-1209.

Glaeser, E., Sacerdore, B., Scheinkman, J. 2003. The social multiplier. Journal of the European Economic Association 1(2-3): 345-353.

Gruber, J., Poterba. J. 1994. Tax incentives and the decision to purchase health insurance: evidence from the self-employed. Quarterly Journal of Economics 109(3), 701-733.

Hong, H., Kubik, J., Stein, J. 2005. Social interaction and stock-market participation. Journal of Finance 59(1), 137-163.

Jones-Smith, J., Popkin, B. 2010. Understanding community context and adult health 
changes in China: development of an urbanicity scale. Social Science and Medicine 71(8), 1436-1446.

Kleven, H., Kopczuk, W. 2011. Transfer program complexity and the take-up of social benefits. American Economic Journal: Economic Policy 3(1): 54-90.

Krueger, A., Kuziemko, I. 2011. The demand for health insurance among uninsured Americans: results of a survey experiment and implications for policy. NBER Working Paper No. 16978.

Lei, X., Lin, W. 2009. The new cooperative medical scheme in rural China: does more coverage mean more service and better health? Health Economics 18(S2), S25-S46.

Li, S., Liu, Y., Deninger, K. 2012. How important are endogenous peer effects in group lending? Estimating a static game of incomplete information. Journal of Applied Econometrics, forthcoming.

Liu, Y. 2004a. China’s public health-care system: facing the challenges. Bulletin of the World Health Organization 82(7), 532-538.

Liu, Y. 2004b. Development of the rural health insurance system in China. Health Policy and Planning 19(3), 159-165.

Liu, Y., Rao, K., Hsiao, W. 2003. Medical expenditure and rural impoverishment in China. Journal of Health, Population and Nutrition 21(3), 213-222.

Mangyo, E., Park, A. 2011. Relative deprivation and health: which reference groups matter? Journal of Human Resources 46(3): 459-481.

Manski, C. 1993. Identification of endogenous social effects: the reflection problem. Review of Economic Studies 60(3), 531-542.

Manski, C. 2000. Economic analysis of social interactions. Journal of Economic Perspectives 14(3), 115-136.

Mao, Z. 2005. Pilot program of NCMS in China: System design and progress. World Bank Report on China Rural Health Study http://siteresources.worldbank.org/INTEAPREGTOPHEANUT/Resources/5027 34-1129734318233/NCMS-report-revisedversion.pdf.

Marquis, M., Long. S. 1995. Worker demand for health insurance in the nongroup 
market. Journal of Health Economics 14(1), 47-63.

Moffitt, R. 1983. An economic model of welfare stigma. American Economic Review 75(5), 1023-1035.

Munshi, K. 2004. Social learning in a heterogeneous population: technology diffusion in the Indian Green Revolution. Journal of Development Economics 73(1), $185-213$.

Munshi, K., Myaux, J. 2006. Social norms and the fertility transition. Journal of Development Economics 80(1), 1-38.

Nair H, Manchanda P, Bhatia T. 2010. Asymmetric social interactions in physician prescription behavior: the role of opinion leaders. Journal of Marketing Research 47(5), 883-895.

Pan, X., Zhang, Y., Xu, L., Huang, J., Zhao, Q. 2009. An analysis of farmers' perception of the new cooperative medical system in Liaoning Province, China. BMC Health Service Research 9:230.

Sommers, B., Kronick, R., Finegold, K., Po, R., Schwartz, K., Glied, S. 2012. Understanding participation rates in Medicaid: implications for the affordable care act. ASPE ISSUE BRIEF, Department of Health and Human Services of the United States.

Sorensen, A. 2006. Social learning and health plan choice. RAND Journal of Economics 37(4), 929-945.

Wagstaff, A., Lindelow, M., Gao, J., Xu, L., Qian, J. 2007. Extending health insurance to the rural population: an impact evaluation of China's New Cooperative Medical Scheme. World Bank Policy Research Working Paper.

Wagstaff, A., Lindelow, M., Jun, G., Ling, X., Qian, J. 2009. Extending health insurance to the rural population: an impact evaluation of China's new cooperative medical scheme. Journal of Health Economics 28(1), 1-19.

Wu, M., Zhang, Z., He, M., Ruan, Y., Lv, C., Tao, L., Miao, M., 2006. Qualitative study on the implementation and determinants of the New Cooperative Medical System in rural China. Study Report from WB/MOH NCMS Study.

Yi, H., Zhang, L., Luo, R., Liu, C., Scott, R. 2011. A survey on farmer's understanding 
of and benefits from New Cooperative Medical Scheme. Population Journal 1(185), 47-53.

Yip, W., Hsiao, W. 2009. China’s health care reform: a tentative assessment. China Economic Review 20(4), 613-619.

Yip, W., Wang, H., Hsiao,W. 2008. The impact of rural mutual health care on access to care: evaluation of a social experiment in rural China. Working Paper, Harvard University.

You, X., Kobayashi, Y. 2009. The new cooperative medical scheme in China. Health Policy 91(1), 1-9. 
Figure 1. NCMS Coverage Rate in Rural China

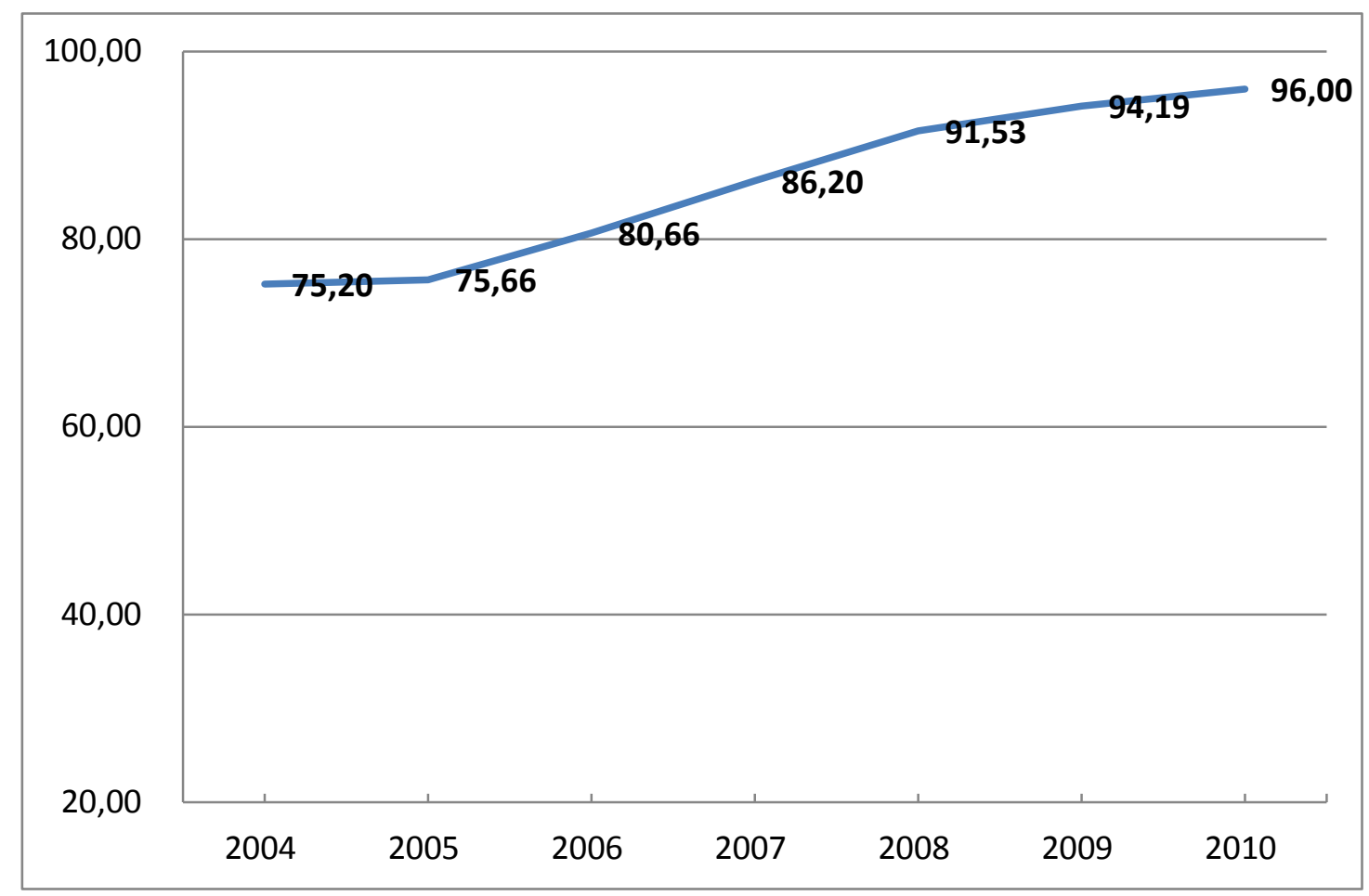

Data source: China Health Statistics Yearbook 2009-2011. 
Table 1. Village-Level Enrollment Rate in Counties with NCMS Newly Introduced

\begin{tabular}{ccccccc}
\hline Wave & $\begin{array}{c}\text { Num. of } \\
\text { counties }\end{array}$ & $\begin{array}{c}\text { Num. of } \\
\text { villages }\end{array}$ & Mean & Std. Dev. & Min & Max \\
\hline 2004 & 6 & 15 & 0.550 & 0.392 & 0 & 1 \\
2006 & 23 & 62 & 0.741 & 0.246 & 0 & 1 \\
2009 & 19 & 51 & 0.886 & 0.198 & 0 & 1 \\
\hline Estimated S.D. of county effect & & 0.193 & \\
Estimated S.D. within counties
\end{tabular}


Table 2. Summary Statistics

\begin{tabular}{|c|c|c|c|c|c|}
\hline \multirow[b]{2}{*}{ Variable } & \multicolumn{2}{|c|}{ Full Sample } & \multirow{2}{*}{$\begin{array}{c}\text { Wave } \\
2004 \\
\text { Mean }\end{array}$} & \multirow{2}{*}{$\begin{array}{c}\text { Wave } \\
2006 \\
\text { Mean }\end{array}$} & \multirow{2}{*}{$\begin{array}{c}\text { Wave } \\
2009 \\
\text { Mean }\end{array}$} \\
\hline & Mean & Std. Dev. & & & \\
\hline \multicolumn{6}{|l|}{ Dependent Variable } \\
\hline Household enrollment status & 0.853 & 0.354 & 0.579 & 0.737 & 0.929 \\
\hline \multicolumn{6}{|l|}{ Explanatory Variables } \\
\hline \multicolumn{6}{|l|}{ Household head's Characteristics } \\
\hline Age & 54.177 & 12.578 & 52.938 & 52.271 & 55.072 \\
\hline Chronic disease & 0.117 & 0.321 & 0.077 & 0.077 & 0.137 \\
\hline Female & 0.153 & 0.360 & 0.193 & 0.140 & 0.154 \\
\hline Married & 0.847 & 0.360 & 0.850 & 0.873 & 0.836 \\
\hline Han & 0.812 & 0.391 & 0.854 & 0.773 & 0.823 \\
\hline Education: primary school & 0.291 & 0.454 & 0.296 & 0.291 & 0.290 \\
\hline Education: junior high school and above & 0.433 & 0.496 & 0.485 & 0.445 & 0.422 \\
\hline \multicolumn{6}{|l|}{ Other Household Characteristics } \\
\hline Household size & 3.532 & 1.596 & 3.279 & 3.482 & 3.579 \\
\hline Total household income(k) & 27.012 & 36.583 & 15.089 & 21.064 & 30.670 \\
\hline Number of children & 0.019 & 0.138 & 0.009 & 0.022 & 0.019 \\
\hline Number of elderly members & 0.748 & 0.434 & 0.678 & 0.797 & 0.736 \\
\hline Number of members with chronic diseases & 0.527 & 0.499 & 0.532 & 0.516 & 0.530 \\
\hline \multicolumn{6}{|l|}{ Village Characteristics } \\
\hline Village population density & 5.257 & 1.364 & 4.796 & 5.219 & 5.321 \\
\hline Village urbanicity index & 51.959 & 13.107 & 50.796 & 47.394 & 53.909 \\
\hline Any health facility in the Village & 0.889 & 0.314 & 0.966 & 0.828 & 0.905 \\
\hline Physician density & 0.014 & 0.177 & 0.000 & 0.046 & 0.003 \\
\hline Village had health insurance in 2000 & 0.382 & 0.486 & 0.335 & 0.441 & 0.364 \\
\hline Prevalence of chronic diseases & 0.074 & 0.055 & 0.052 & 0.054 & 0.084 \\
\hline Communication score & 5.765 & 1.424 & 5.016 & 5.431 & 6.028 \\
\hline Access to convenient internet service & 0.488 & 0.500 & 0.365 & 0.313 & 0.597 \\
\hline Access to convenient cell phone service & 0.807 & 0.395 & 0.845 & 0.697 & 0.863 \\
\hline Number of household observations & \multicolumn{2}{|c|}{3266} & 233 & 866 & 2167 \\
\hline Number of villages & & & 15 & 75 & 129 \\
\hline Number of NCMS cities/counties & & & 6 & 28 & 48 \\
\hline
\end{tabular}

Note: in each wave of CHNS 2004-2009, there are 54 sample cities or counties. 
Table 3. Social Effects of NCMS Enrollment

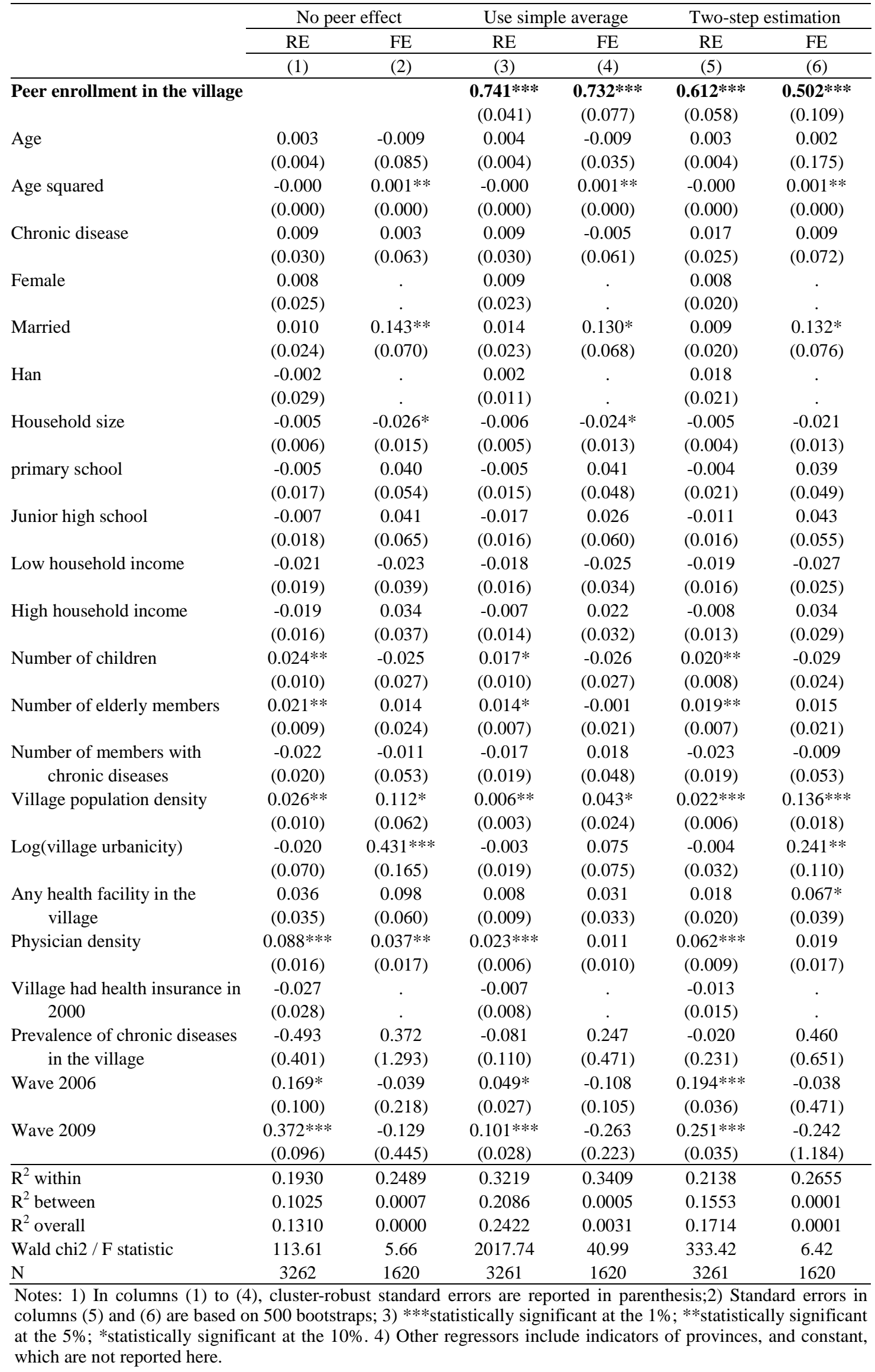


Table 4. Nonlinear Social Effects of NCMS Enrollment

\begin{tabular}{|c|c|c|c|c|}
\hline & \multicolumn{2}{|c|}{ Use Quadratic Forms } & \multicolumn{2}{|c|}{ Use Linear Splines } \\
\hline & $\mathrm{RE}$ & $\mathrm{FE}$ & $\mathrm{RE}$ & $\mathrm{FE}$ \\
\hline & $(1)$ & $(2)$ & (3) & (4) \\
\hline Peer enrollment in the village & $\begin{array}{c}3.143 * * * \\
(0.563)\end{array}$ & $\begin{array}{c}3.619 * * * \\
(0.723)\end{array}$ & & \\
\hline Squared peer enrollment & $\begin{array}{c}-1.653 * * * \\
(0.351)\end{array}$ & $\begin{array}{c}-2.053 * * * \\
(0.456)\end{array}$ & & \\
\hline $\begin{array}{l}\text { Peer enrollment in the village: } 0 \text { - } \\
\quad 0.6\end{array}$ & & & $\begin{array}{c}1.381^{* * *} \\
(0.417)\end{array}$ & $\begin{array}{c}1.449 * * * \\
(0.553)\end{array}$ \\
\hline $\begin{array}{l}\text { Peer enrollment in the village: } 0.6 \text { - } \\
\quad 0.9\end{array}$ & & & $\begin{array}{c}\mathbf{0 . 7 1 0} \\
(0.123)\end{array}$ & $\begin{array}{r}\mathbf{0 . 6 6 6}^{* * *} \\
(0.243)\end{array}$ \\
\hline $\begin{array}{l}\text { Peer enrollment in the village: } 0.9 \\
\text { and above }\end{array}$ & & & $\begin{array}{l}-\mathbf{0 . 2 9 8} \\
(0.304)\end{array}$ & $\begin{array}{l}\mathbf{- 0 . 7 5 1} \\
(0.527)\end{array}$ \\
\hline Wave 2006 & $\begin{array}{l}0.154 * * * \\
(0.031)\end{array}$ & $\begin{array}{l}0.080^{*} \\
(0.047)\end{array}$ & $\begin{array}{c}0.156^{* * *} \\
(0.033)\end{array}$ & $\begin{array}{c}0.076 \\
(0.054)\end{array}$ \\
\hline Wave 2009 & $\begin{array}{l}0.203 * * * \\
(0.035)\end{array}$ & $\begin{array}{l}0.090^{*} \\
(0.048)\end{array}$ & $\begin{array}{l}0.202 * * * \\
(0.031)\end{array}$ & $\begin{array}{c}0.080 \\
(0.060)\end{array}$ \\
\hline Control of household characteristics & Yes & Yes & Yes & Yes \\
\hline Control of village characteristics & Yes & Yes & Yes & Yes \\
\hline Control of provincial dummies & Yes & Yes & Yes & Yes \\
\hline $\mathrm{N}$ & 3261 & 1620 & 3261 & 1620 \\
\hline
\end{tabular}

Notes: Standard errors based on 500 bootstraps are reported in parenthesis; ***statistically significant at the $1 \%$; **statistically significant at the $5 \%$; *statistically significant at the $10 \%$. 
Table 5. Social Effects by NCMS Implementation Time

\begin{tabular}{|c|c|c|c|c|}
\hline & \multirow{2}{*}{\multicolumn{3}{|c|}{$\begin{array}{c}\text { Villages with NCMS } \\
\text { Newly Introduced in Each Wave }\end{array}$}} & \multirow{3}{*}{$\begin{array}{l}\text { All Villages } \\
\text { CHNS } 2009\end{array}$} \\
\hline & & & & \\
\hline & CHNS 2004 & CHNS 2006 & CHNS 2009 & \\
\hline & (1) & (2) & (3) & (4) \\
\hline \multirow[t]{2}{*}{ Peer enrollment in the village } & $1.391 * *$ & $0.870 * * *$ & $0.532 * * *$ & $0.670 * * *$ \\
\hline & $(0.612)$ & $(0.115)$ & $(0.165)$ & $(0.131)$ \\
\hline Peer enrollment $\times$ NCMS & & & & $-0.387 * *$ \\
\hline introduced in wave 2006 & & & & $(0.164)$ \\
\hline Peer enrollment $\times$ NCMS & & & & $-0.697 * *$ \\
\hline introduced in wave 2004 & & & & $(0.291)$ \\
\hline NCMS introduced in wave 2009 & & & & Reference \\
\hline \multirow[t]{2}{*}{ NCMS introduced in wave 2006} & & & & $0.350 * *$ \\
\hline & & & & $(0.148)$ \\
\hline \multirow[t]{2}{*}{ NCMS introduced in wave 2004} & & & & $0.650 * *$ \\
\hline & & & & $(0.255)$ \\
\hline Control of household characteristics & Yes & Yes & Yes & Yes \\
\hline Control of village characteristics & Yes & Yes & Yes & Yes \\
\hline Control of provincial dummies & Yes & Yes & Yes & Yes \\
\hline Control of wave dummies & - & -- & -- & - \\
\hline $\mathrm{N}$ & 233 & 819 & 866 & 2162 \\
\hline
\end{tabular}

Notes: Standard errors based on 500 bootstraps are reported in parenthesis; ***statistically significant at the $1 \%$; **statistically significant at the $5 \%$; *statistically significant at the $10 \%$. 
Table 6. Social Effects by Communication Levels of the Village

\begin{tabular}{|c|c|c|c|}
\hline & $\begin{array}{l}\text { Interacted with the } \\
\text { overall } \\
\text { communication } \\
\text { level of the village }\end{array}$ & $\begin{array}{c}\text { Interacted with } \\
\text { access to } \\
\text { convenient internet } \\
\text { service in the } \\
\text { village }\end{array}$ & $\begin{array}{l}\text { Interacted with } \\
\text { access to } \\
\text { convenient cell } \\
\text { phone service in } \\
\text { the village } \\
\end{array}$ \\
\hline & (1) & $(2)$ & (3) \\
\hline \multirow[t]{2}{*}{ Peer enrollment in the village } & $1.266^{* * *}$ & $0.683^{* * *}$ & $0.960 * * *$ \\
\hline & $(0.282)$ & $(0.167)$ & $(0.195)$ \\
\hline \multirow[t]{2}{*}{ Peer enrollment $\times$ communications score } & $-0.138 * * *$ & & \\
\hline & $(0.046)$ & & \\
\hline \multirow[t]{2}{*}{ Peer enrollment $\times$ convenient internet service } & & $-0.418 * *$ & \\
\hline & & $(0.207)$ & \\
\hline \multirow[t]{2}{*}{ Peer enrollment $\times$ convenient cell phone service } & & & $-0.537 * * *$ \\
\hline & & & $(0.196)$ \\
\hline \multirow[t]{2}{*}{ Communications score of the village } & $0.116^{* * *}$ & & \\
\hline & $(0.039)$ & & \\
\hline \multirow[t]{2}{*}{ Access to convenient internet service } & & $0.363 * *$ & \\
\hline & & $(0.178)$ & \\
\hline \multirow[t]{2}{*}{ Access to convenient cell phone service } & & & $0.412 * * *$ \\
\hline & & & $(0.148)$ \\
\hline Control of household characteristics & Yes & Yes & Yes \\
\hline Control of village characteristics & Yes & Yes & Yes \\
\hline Control of provincial dummies & Yes & Yes & Yes \\
\hline Control of wave dummies & Yes & Yes & Yes \\
\hline $\mathrm{N}$ & 1620 & 1620 & 1620 \\
\hline
\end{tabular}

Notes: Standard errors based on 500 bootstraps are reported in parenthesis; ***statistically significant at the $1 \%$;

**statistically significant at the $5 \%$; *statistically significant at the $10 \%$. 
Table 7. Social Effects from Different Villages and Counties

\begin{tabular}{|c|c|c|c|c|c|c|c|c|}
\hline & \multicolumn{4}{|c|}{ Random Effect } & \multicolumn{4}{|c|}{ Fixed Effect } \\
\hline & $(1)$ & $(2)$ & (3) & (4) & (5) & (6) & (7) & (8) \\
\hline Peer enrollment in the & $0.612 * * *$ & & & $0.736 * * *$ & $0.502^{* * *}$ & & & $0.534 * * *$ \\
\hline village & $(0.058)$ & & & $(0.089)$ & $(0.109)$ & & & $(0.177)$ \\
\hline Peer enrollment in other & & $0.319 * * *$ & & -0.000 & & 0.133 & & -0.146 \\
\hline villages of the county & & $(0.049)$ & & $(0.078)$ & & $(0.093)$ & & $(0.176)$ \\
\hline Peer enrollment in other & & & -0.095 & 0.195 & & & 0.011 & -0.057 \\
\hline counties of the province & & & $(0.158)$ & $(0.130)$ & & & $(0.180)$ & $(0.218)$ \\
\hline $\begin{array}{l}\text { Control of household } \\
\text { characteristics }\end{array}$ & Yes & Yes & Yes & Yes & Yes & Yes & Yes & Yes \\
\hline $\begin{array}{c}\text { Control of village } \\
\text { characteristics }\end{array}$ & Yes & Yes & Yes & Yes & Yes & Yes & Yes & Yes \\
\hline $\begin{array}{l}\text { Control of provincial } \\
\text { dummies }\end{array}$ & Yes & Yes & Yes & Yes & Yes & Yes & Yes & Yes \\
\hline Control of wave dummies & Yes & Yes & Yes & Yes & Yes & Yes & Yes & Yes \\
\hline $\mathrm{N}$ & 3261 & 3225 & 3029 & 2991 & 1620 & 1614 & 1308 & 1302 \\
\hline
\end{tabular}


Table 8. Social Effects from Different Subgroups in the Village

\begin{tabular}{|c|c|c|c|c|}
\hline \multirow{3}{*}{ Fixed Effect Estimation } & $(1)$ & $(2)$ & $(3)$ & $(4)$ \\
\hline & \multicolumn{4}{|c|}{ Panel 1: group by household head's age in the village } \\
\hline & Full Sample & Age 18-54 & Age 55 and above & \\
\hline \multirow{2}{*}{$\begin{array}{l}\text { Peer enrollment in group age } \\
18-54\end{array}$} & 0.143 & 0.085 & 0.218 & \\
\hline & $(0.139)$ & $(0.188)$ & $(0.236)$ & \\
\hline \multirow{2}{*}{$\begin{array}{l}\text { Peer enrollment in group age } \\
55 \text { and above }\end{array}$} & $0.397 * * *$ & $0.467 * * *$ & 0.293 & \\
\hline & $(0.124)$ & $(0.148)$ & $(0.288)$ & \\
\hline \multirow[t]{3}{*}{$\mathrm{N}$} & 1572 & 779 & 630 & \\
\hline & \multicolumn{4}{|c|}{ Panel 2: group by household head's nationality in the village } \\
\hline & Full Sample & Han & Minorities & \\
\hline \multirow[t]{2}{*}{ Peer enrollment in Han group } & $0.299 * * *$ & $0.456 * * *$ & 0.165 & \\
\hline & $(0.074)$ & $(0.103)$ & $(0.181)$ & \\
\hline \multirow{2}{*}{$\begin{array}{l}\text { Peer enrollment in minorities’ } \\
\text { group }\end{array}$} & 0.121 & 0.089 & -0.227 & \\
\hline & $(0.080)$ & $(0.064)$ & $(0.424)$ & \\
\hline \multirow[t]{3}{*}{$\mathrm{N}$} & 1600 & 1262 & 338 & \\
\hline & \multicolumn{4}{|c|}{ Panel 3: group by household head's gender in the village } \\
\hline & Full Sample & Male & Female & \\
\hline \multirow{2}{*}{$\begin{array}{l}\text { Peer enrollment in Male } \\
\text { group }\end{array}$} & $0.515 * * *$ & $0.389 * *$ & $1.176^{*}$ & \\
\hline & $(0.142)$ & $(0.153)$ & $(0.582)$ & \\
\hline \multirow{2}{*}{$\begin{array}{l}\text { Peer enrollment in Female } \\
\text { group }\end{array}$} & 0.025 & 0.087 & -0.187 & \\
\hline & $(0.116)$ & $(0.123)$ & $(0.416)$ & \\
\hline \multirow[t]{3}{*}{$\mathrm{N}$} & 1405 & 1224 & 181 & \\
\hline & Panel 4: g & y household & d's education level & ne village \\
\hline & Full Sample & $\begin{array}{l}\text { Below } 30^{\text {th }} \\
\text { percentile }\end{array}$ & $\begin{array}{c}\text { Between } 30-70^{\text {th }} \\
\text { percentile }\end{array}$ & $\begin{array}{l}\text { Above } 70^{\text {th }} \\
\text { percentile }\end{array}$ \\
\hline \multirow{2}{*}{$\begin{array}{l}\text { Peer enrollment in group with } \\
\text { low education }\end{array}$} & -0.005 & -0.156 & 0.308 & 0.127 \\
\hline & $(0.140)$ & $(0.501)$ & $(0.261)$ & $(0.246)$ \\
\hline \multirow{2}{*}{$\begin{array}{l}\text { Peer enrollment in group with } \\
\text { mid education }\end{array}$} & 0.030 & 0.783* & -0.205 & 0.112 \\
\hline & $(0.274)$ & $(0.398)$ & $(0.279)$ & $(0.222)$ \\
\hline \multirow{2}{*}{$\begin{array}{l}\text { Peer enrollment in group with } \\
\text { high education }\end{array}$} & 0.308 & -0.026 & 0.367 & -0.075 \\
\hline & $(0.241)$ & $(0.723)$ & $(0.308)$ & $(0.281)$ \\
\hline \multirow[t]{3}{*}{$\mathrm{N}$} & 1205 & 172 & 274 & 407 \\
\hline & \multicolumn{4}{|c|}{ Panel 5: group by household income level in the village } \\
\hline & Full Sample & $\begin{array}{l}\text { Below } 30^{\text {th }} \\
\text { percentile }\end{array}$ & $\begin{array}{c}\text { Between } 30-70^{\text {th }} \\
\text { percentile }\end{array}$ & $\begin{array}{l}\text { Above } 70^{\text {th }} \\
\text { percentile }\end{array}$ \\
\hline \multirow{2}{*}{$\begin{array}{l}\text { Peer enrollment in group with } \\
\text { low HH income }\end{array}$} & 0.048 & -0.563 & 0.257 & 0.084 \\
\hline & (0.138) & $(0.414)$ & $(0.332)$ & $(0.227)$ \\
\hline \multirow{2}{*}{$\begin{array}{l}\text { Peer enrollment in group with } \\
\text { mid HH income }\end{array}$} & 0.140 & $0.750^{*}$ & -0.647 & 0.413 \\
\hline & $(0.147)$ & $(0.392)$ & (0.397) & $(0.374)$ \\
\hline \multirow{2}{*}{$\begin{array}{l}\text { Peer enrollment in group with } \\
\text { high HH income }\end{array}$} & $0.319 * * *$ & 0.043 & $0.510 *$ & 0.023 \\
\hline & $(0.089)$ & $(0.504)$ & $(0.288)$ & $(0.207)$ \\
\hline $\mathrm{N}$ & 1619 & 216 & 294 & 247 \\
\hline
\end{tabular}

Notes: 1) Standard errors based on 500 bootstraps are reported in parenthesis; ***statistically significant at the $1 \%$; **statistically significant at the $5 \%$; *statistically significant at the $10 \%$. 2) Other regressors include all explanatory variables listed in Table 3, indicators of provinces and constant, which are not reported here. 
Table 9. Social Effects and Adverse Selection

\begin{tabular}{|c|c|c|c|c|}
\hline \multirow{3}{*}{ Fixed Effect Estimation } & $(1)$ & $(2)$ & $(3)$ & $(4)$ \\
\hline & \multicolumn{4}{|c|}{$\begin{array}{l}\text { Panel 1. Interacted with/group by household head's chronic disease } \\
\text { status }\end{array}$} \\
\hline & Full Sample & Full Sample & $\begin{array}{c}\text { No Chronic } \\
\text { Disease }\end{array}$ & $\begin{array}{c}\text { With Chronic } \\
\text { Disease }\end{array}$ \\
\hline Peer enrollment in the village & $\begin{array}{c}0.534 * * * \\
(0.084)\end{array}$ & & & \\
\hline $\begin{array}{l}\text { Peer enrollment } \times \text { household head has } \\
\text { chronic disease }\end{array}$ & $\begin{array}{l}-\mathbf{0 . 4 5 0 *} \\
(0.2089)\end{array}$ & & & \\
\hline Household head has chronic disease & $\begin{array}{l}0.371^{*} \\
(0.184)\end{array}$ & & & \\
\hline $\begin{array}{l}\text { Peer enrollment in subgroup without } \\
\text { chronic disease }\end{array}$ & & $\begin{array}{c}\mathbf{0 . 7 4 8} * * * \\
(0.155)\end{array}$ & $\begin{array}{c}\mathbf{0 . 8 2 7 * * *} \\
(0.175)\end{array}$ & $\begin{array}{c}0.662 \\
(0.617)\end{array}$ \\
\hline $\begin{array}{l}\text { Peer enrollment in subgroup with } \\
\text { chronic disease }\end{array}$ & & $\begin{array}{l}-0.078 \\
(0.087)\end{array}$ & $\begin{array}{l}-0.166^{*} \\
(0.108)\end{array}$ & $\begin{array}{l}-0.717 \\
(0.734)\end{array}$ \\
\hline \multirow[t]{3}{*}{$\mathrm{N}$} & 1620 & 1062 & 883 & 77 \\
\hline & \multicolumn{4}{|c|}{$\begin{array}{l}\text { Panel 2. Interacted with/group by household member’s chronic } \\
\text { disease status }\end{array}$} \\
\hline & Full Sample & Full Sample & $\begin{array}{l}\text { Sample } \\
\text { without } \\
\text { Chronic } \\
\text { Disease } \\
\end{array}$ & $\begin{array}{c}\text { Sample With } \\
\text { Chronic } \\
\text { Disease }\end{array}$ \\
\hline Peer enrollment in the village & $\begin{array}{c}0.567 * * * \\
(0.124)\end{array}$ & & & \\
\hline $\begin{array}{l}\text { Peer enrollment } \times \text { household member } \\
\text { has chronic disease }\end{array}$ & $\begin{array}{c}\mathbf{- 0 . 3 9 3 * *} \\
(0.181)\end{array}$ & & & \\
\hline Household member has chronic disease & $\begin{array}{l}0.483 * * * \\
(0.159)\end{array}$ & & & \\
\hline $\begin{array}{l}\text { Peer enrollment in subgroup without } \\
\text { chronic disease }\end{array}$ & & $\begin{array}{c}\mathbf{0 . 5 4 0 * * *} \\
(0.134)\end{array}$ & $\begin{array}{c}\mathbf{0 . 6 8 3} * * * \\
(0.155)\end{array}$ & $\begin{array}{c}\mathbf{0 . 6 9 6 * *} \\
(0.307)\end{array}$ \\
\hline $\begin{array}{l}\text { Peer enrollment in subgroup with has } \\
\text { chronic disease }\end{array}$ & & $\begin{array}{c}0.018 \\
(0.080)\end{array}$ & $\begin{array}{l}-0.083 \\
(0.116)\end{array}$ & $\begin{array}{c}0.120 \\
(0.364)\end{array}$ \\
\hline $\mathrm{N}$ & 1620 & 1364 & 952 & 149 \\
\hline
\end{tabular}

Notes: 1) Standard errors based on 500 bootstraps are reported in parenthesis ***statistically significant at the $1 \%$; **statistically significant at the 5\%; *statistically significant at the $10 \%$. 2) Other regressors include all explanatory variables listed in Table 2, indicators of provinces and constant, which are not reported here; 
Table 10. Social Effect and Financial Need

\begin{tabular}{|c|c|c|}
\hline \multirow[t]{2}{*}{ Fixed Effect Estimation } & $\begin{array}{c}\text { Interacted with } \\
\text { household income }\end{array}$ & $\begin{array}{c}\text { Interacted with village } \\
\text { urbanicity score }\end{array}$ \\
\hline & (1) & (2) \\
\hline \multirow[t]{2}{*}{ Peer enrollment in the village } & $0.259 * *$ & $0.340 * *$ \\
\hline & $(0.126)$ & $(0.142)$ \\
\hline \multirow[t]{2}{*}{ Peer enrollment $\times$ low household income } & $0.618^{* * *}$ & \\
\hline & $(0.145)$ & \\
\hline \multirow[t]{2}{*}{ Peer enrollment $\times$ high household income } & 0.048 & \\
\hline & $(0.179)$ & \\
\hline \multirow[t]{2}{*}{ Peer enrollment $\times$ low urbanicity index } & & $0.635^{* * *}$ \\
\hline & & $(0.175)$ \\
\hline \multirow[t]{2}{*}{ Peer enrollment $\times$ high urbanicity index } & & 0.165 \\
\hline & & $(0.188)$ \\
\hline \multirow[t]{2}{*}{ Lowest 30\% } & $-0.495 * * *$ & $-0.522 * * *$ \\
\hline & $(0.117)$ & $(0.137)$ \\
\hline \multirow[t]{2}{*}{ Highest 30\% } & -0.000 & -0.168 \\
\hline & $(0.147)$ & $(0.153)$ \\
\hline Control of household characteristics & Yes & Yes \\
\hline Control of village characteristics & Yes & Yes \\
\hline Control of provincial dummies & Yes & Yes \\
\hline Control of wave dummies & Yes & Yes \\
\hline $\mathrm{N}$ & 1620 & 1620 \\
\hline
\end{tabular}

Notes: Standard errors based on 500 bootstraps are reported in parenthesis; ***statistically significant at the $1 \%$; **statistically significant at the $5 \%$; *statistically significant at the $10 \%$. 